\title{
FROM VALUE CO-CREATION TO POSITIVE EXPERIENCES AND CUSTOMER SATISFACTION. A CUSTOMER PERSPECTIVE IN THE HOTEL INDUSTRY
}

\author{
Konstantinos SOLAKIS (iD) 1 , Jesús PEÑA-VINCES (D) 2*, \\ Jesús M. LOPEZ-BONILLA (D) ${ }^{3}$, Luis F. AGUADO (D) 4 \\ ${ }^{1}$ Department of Tourism Management, University of West Attica, Egaleo, Greece \\ ${ }^{2,3}$ Department of Business Management, Faculty of Economics and Business, \\ Universidad de Sevilla, Sevilla, Spain \\ ${ }^{4}$ Department of Economics, Faculty of Business and Economics Sciences, \\ Pontificia Universidad Javeriana, Seccional Cali, Cali, Colombia
}

Received 15 December 2020; accepted 16 May 2021

\begin{abstract}
This study evaluates whether the Value Co-creation (VCC) process in hotels contributes to positive guest experience and satisfaction. This paper utilizes the DART model (Dialogue, Access, Risk, and Transparency) as the main framework to explore VCC in hotels. This research is the first to both adjust the DART model to a customer's viewpoint and evaluate it in the hotel context. The included data is derived from 484 international tourists lodged in Greek hotels and is analyzed with the structural equation modeling technique. Results suggest that the Dialogue component of DART does not affect the positive experience, while Access, Transparency, and Risk Assessment do, in fact, strongly influence tourist satisfaction. The current study enriches and consolidates VCC-DART theory in the hotel context.
\end{abstract}

Keywords: DART model, Value Co-creation, positive experience, customer satisfaction, hotel industry.

JEL Classification: D9, M31, D46.

\section{Introduction}

Technological advancements and empowered consumers have changed the marketing perspective - a new era is emerging in service marketing in which a customer can use knowledge, skills, and power to interact with a firm's VCC process (Buhalis \& Foerste, 2014; Buhalis \& Leung, 2018). At the core of the new service-marketing reality is Value Co-creation, and concern emerges on how customers co-create. Despite extensive research on VCC, several operational frameworks, measurement tools, contributions to managerial applications, and implications have been minimal (Galvagno \& Dalli, 2014; Saha et al., 2020).

${ }^{\star}$ Corresponding author. E-mail: jesuspvinces@us.es

Copyright (c) 2021 The Author(s). Published by Vilnius Gediminas Technical University

This is an Open Access article distributed under the terms of the Creative Commons Attribution License (http://creativecommons. org/licenses/by/4.0/), which permits unrestricted use, distribution, and reproduction in any medium, provided the original author and source are credited. 
One of the first and most influential VCC models is DART, established by Prahalad and Ramaswamy (2004a). DART consists of Dialogue, Access, Risk Assessment. and Transparency: the four building blocks of interaction which are essential to VCC. These blocks are meant to provoke reciprocal interaction between the companies and the customers that are considered as equal actors (Prahalad \& Ramaswamy, 2004a). The simplicity and efficiency of the DART model to enhance VCC (González-Mansilla et al., 2019; Zaborek \& Mazur, 2019) makes it the appropriate choice. In contrast to other models, DART has been applied to and tested in the real world by organizations like Nike (Ramaswamy, 2008), a world-renowned athletics company, and that is the reason this model deserves attention.

However, the DART model has been poorly assessed in tourism and the hotel industry (González-Mansilla et al., 2019; Solakis et al., 2017), providing the opportunity for this study to fill the gap. Tourism and hotel industries require more research concerning the process of VCC (Chathoth et al., 2016; Morosan, 2018; Shaw et al., 2011), while the VCC process appears to have a substantial effect on how consumers assess services (Heidenreich et al., 2015) and their satisfaction (Ranjan \& Read, 2014). DART functions with a hotel's customer satisfaction through service experiences, since customer participation during VCC is an experience in itself (Prahalad \& Ramaswamy, 2004c). The result of the experience determines the degree of satisfaction (Xiang et al., 2015).

The DART model was originally designed to evaluate VCC in a company context. However, to observe VCC's effects on customer experience and satisfaction, the measurement scale is modified and adjusted to a customer's perspective. Insight is then collected on how guests perceive the hotel's VCC procedures. This approach is aligned with the principles of dialogue; the heart of the VCC procedure (Prahalad \& Ramaswamy, 2004a). The building blocks of interaction apply not only to the firms but also to customers, since the dialogue occurs between equal partners (Prahalad \& Ramaswamy, 2004b) and has become difficult to distinguish producers from consumers (Ramaswamy, 2011).

The DART model was chosen as a framework to analyze VCC in hotels, since most current lodging research based on the model differs significantly from our research (as they were performed from a business perspective). This study assesses the DART model from a customer's perspective, which will reveal whether or not VCC exists among hotels and their customers. Gallarza and Gil Saura (2020, p. 43) propose that in the next 75 years, research must focus on customer value. Digitization disturbed the value provision, and marketers must "...assure value co-creation through context-based, marketing social media and higher customization”. Gajdošík et al. (2020) suggest that potential studies should concentrate on the personalized experiences of tourists. Research on co-creation in tourism and hotels has increased in recent years (Mohammadi et al., 2021). Few empirical studies examine the VCC with hotel customers, (Campos et al., 2018) while Mohammadi et al. (2021) suggest that research should focus on the process and methods of VCC in the tourism industry.

This article aims to explore the mechanisms of VCC in the hotel context, and whether it enhances hotel guest experience. To achieve this, the DART model is utilized as a VCC roadmap for hotels. The objectives are (1) to assess the reliability and validity of the DART scale from a consumer perspective in the hotel industry, and (2) to analyze the relationships in the model regarding positive experience and hotel guest satisfaction. 


\section{Literature review}

\subsection{DART model}

DART was introduced by Prahalad and Ramaswamy (2004a, 2004c) as an apparatus for firms to co-create value with their customers. Ramaswamy (2008) presented the Nike + platform case study as a successful example of the DART guideline application. It states that the four building blocks of interaction allow high-quality co-creative interactions between the firm and the consumers, the consumers with each other, and between firms (Nike and Apple).

The DART model was used as the main framework because it constitutes one of the main theories and is broadly used when studying the concept of VCC. Prahalad and Ramaswamy (2004a) suggested that by using the DART model, the relationship between a customer and organization is established, becoming the central pillar of value creation. The DART model tries to explain the core features of VCC between consumers and businesses. According to Prahalad and Ramaswamy (2004c), such a model can be applied to any services sector, but particularly to the hotel industry. As one of the main characteristics of that sector, the cocreation of value is based on the search for the client's own experiences. It is common practice in the hotel industry to gather knowledge regarding customers preferences, and to encourage those clients to engage in hotel procedures since "co-creation is also an interactive process that depends not only on corporate actions but also on customers' active participation in creating their consumer experience" (González-Mansilla et al., 2019, p. 53).

Lazarus et al. (2014) argue that DART provides a more critical, dynamic, and bi-directional perspective that is based on interactions between company and client, which themselves are based on service encounters. Research demonstrates that many measurement scales exist in customer co-creation of value. However, most research criticizes them due to multidimensionality and colossal extensions, which results in difficulty with application and validation (Ranjan \& Read, 2014). In smaller scales, the primary difficulty is multidimensionality (Mathis et al., 2016; Polo Peña et al., 2014). Following Yi and Gong (2013), an abbreviated scale based on DART was constructed to benefit researchers.

Few researchers proceeded on an evaluation of the model. In a qualitative study of store experiences and co-creation, Spena et al. (2012) use DART as a theoretical framework, from a firm's perspective. Their results indicate that temporary stores in Italy co-create value with customers by implementing the four building blocks of interaction. Mazur and Zaborek (2014) show that in service and manufacturing companies, the DART model is not the most appropriate model to represent co-creation. Taghizadeh et al. (2016) developed a scale for DART, applying it to innovation strategy and market performance. Results indicated a robust positive correlation between the four building blocks of interaction and innovation strategy. A scale was developed by Albinsson et al. (2016) for the DART model from a firm's perspective, evaluating service loyalty and shared responsibilities. Researchers investigated if indeed shared responsibilities contributed to high DART assessments and meaningful evaluations of customer loyalty. Findings suggest an affirmative association between shared responsibility and DART, but various implications indicate that only the pillar of Access interacted with loyalty. Chen et al. (2017) tested a modified DART model, introducing Flexibility and Compatibility as the fifth and sixth pillars of the model, using travel agencies in a B2B context 
as an example. Results suggested that business co-creation enhances service innovation in travel agencies.

In conclusion, the traditional accommodation industry has not been used as a context for evaluation since it has always observed a firm's perspective. This research acknowledges the role of customers as equal partners during VCC in the dialogical process, meaning the model can also serve customers. The values of the DART model apply to all actors equally; an argument that highlights the demarcation between producers and consumers as barely clear (Ramaswamy, 2011). To evaluate the new model from the customers' perspective, the article fosters an adjusted measurement scale providing information on customers and how they perceive VCC with hotels.

\subsection{VCC with hotel guests}

The hotel industry operates in a dynamic environment with very demanding consumers seeking quality services, functionality, and aesthetically pleasing facilities (González-Mansilla et al., 2019). Due to advancement of Information and Communication Technology (ICT), hotel value propositions evolved from homogenous goods and services to personalized hotel experiences (Neuhofer, 2016). It has never been easier to collect reserve and retrieve data concerning hotel guest behaviour from both internal and external hotel resources. Such data is related to: length of stay, money spent on the hotel stay, and purchased services. Data has become more personal, including guest allergies and preferred dishes. This data can be utilized by hotel managers to forecast guest needs and preferences, offering personalized and high-quality experiences (Neuhofer et al., 2015). As Majboub (2014, p. 27) suggests, "tourism providers need to create experience environments, integrating resources to co-create highvalue experience". Whereas, Prahalad and Ramaswamy (2004b, p. 7) posit that "high-quality interactions that enable an individual customer to co-create unique experiences with the company are the key to unlocking new sources of competitive advantage".

As a consequence, customers' experiences are essential for successful hotels (Xiang et al., 2015). Ramaswamy (2011) argues that human experiences are what markets are all about, and firms should need not be service-oriented nor experience-oriented. Experiences stem from interactions, while VCC and customer experiences interrelate as VCC is an experience in itself (Ramaswamy, 2011).

In a hotel context, opportunities for physical or digital direct interactions between employees and guests - or guests and robots - are inevitable and numerous since production and consumption coincide (Fan et al., 2019; Zhang, 2019). Experiences perceived from these encounters are meaningful, as they create value and define customer satisfaction (FemeniaSerra et al., 2019). Given the importance of the customer experience aspect in the hotel and tourism industries, empirical evidence is scarce in this context (Ingram et al., 2017). Using one or more of the DART components in the hotel industry may produce compelling experiences.

\subsubsection{Dialogue}

Dialogue in the context of a hotel means that guests communicate with the hotel, and vice versa. To promote and encourage Dialogue, a firm must offer multiple diverse channels of 
communication, allowing customers the freedom to choose the way they interact (Buhalis \& Leung, 2018). Hotel guests can interact and communicate at any time with hotel staff, through traditional (face to face dialogue) and non-traditional (websites, mobile applications, robots) communication channels (Buhalis \& Leung, 2018; Fan et al., 2019). When actors initiate Dialogue through a communication channel, guest experience is affected. The quality of communication is significant, and hotels must ensure consistent quality experiences throughout communication channels (Rather \& Sharma, 2017). For example, a guest can request a wake-up call by calling reception from their room phone, through a smart $\mathrm{TV}$, or in a smartphone application. A variety of options can appeal to each type of guest, satisfying diverse needs and creating positive experiences. Huang et al. (2019) highlight that perceived user-friendliness and usability of hotel smartphone applications positively affects hotel guest experience.

However, communication channels alone are insufficient; hotels must also encourage Dialogue to ensure guests feel their arguments, suggestions, and complaints are heard (GonzálezMansilla et al., 2019; Grönroos, 2004). Buhalis and Leung (2018) mention "smartness" in hotels, a state where Information and Communication Technology (ICT) is utilized to collect, process, and exchange information from the hotel's ecosystem to co-create experiences with their guests. This means there must be feedback procedures that ensure customer involvement during VCC (Zhang, 2019). The quality of Dialogue defines the outcome of the co-created experience (González-Mansilla et al., 2019). Hotels that offer unique, positive experiences to guests provide a diversity of communication channels designed to provide opportunities for dynamic discourse (Fan et al., 2019). Therefore, this is the first proposed hypothesis:

\section{H1. Dialogue with a hotel enhances customers' experiences.}

\subsubsection{Access}

Access refers to the degree of openness and level of restriction that the business places upon the information released to customers. Access considers the type of information and necessary tools required to enable customers to make informed decisions about the business and its products. Access enhances the customer experience by facilitating more efficient Dialogue (Albinsson et al., 2016). This occurs as firms share their knowledge and tools with customers, and advancements in ICT have improved this ability. With Access, hotel guests can ask and shape their experiences dynamically. Hotel guests do not merely purchase pre-designed services, but pursue positive, exciting experiences through personal involvement and consumption (Buhalis \& Leung, 2018). Through access to information and tools, hotel guests can engage in and design their own experiences to fit their lifestyle. Within the hotel context, Access as a component of DART is essential in providing customized, positive experiences (Neuhofer et al., 2015). Customers will not only feel a sense of acceptance, but may also accredit accountability to the system when the business provides little or no restrictions to information about its operations, thereby contributing to a positive customer experience. Thus, the second hypothesis is:

H2. A hotel's accessibility through customer information and tools enhances customers' experiences. 


\subsubsection{Risk}

Risk is a factor that can be contingent on the degree of Access. Risk considers the extent in which the information provided by the business clarifies the perils and liabilities associated with the business and its products (Damali et al., 2020). To access this level of Risk, customers as active co-creators require adequate information about the organization's internal processes, ethics, practices, and values to therefore assess the possible uncertainties of associating with the business or partaking in the co-creation process.

Accessing services and information looms threats for all actors. There is the propensity for hotel managers to communicate only the benefits of a hotel stay, failing to disclose potential dangers (Kuo et al., 2015). Examples could include a pool cleaned with detergents that are environmentally unfriendly, or a hotel poorly informing customers about evacuation procedures (Nguyen et al., 2018), ultimately leading to an unpleasant experience. It is the firm's responsibility to inform customers of the advantages as well as the disadvantages of their products. This way, the firm dynamically supports customers to reach an informed decision and establishes trust between them; a component of customer satisfaction and retention (Damali et al., 2020). The contemporary business environment is characterized by networking and increased customer communication (Buhalis, 2019). Because of this, customers may discuss the Risk associated with a service provider in a dedicated community, such as TripAdvisor or Booking.com. Deceptive information can lead to mistrust, while the absence of information presents a company as dishonest and unscrupulous.

The timely provision of information about Risks through official communication channels allows customers to assess the quality of services and choose a hotel that provides specific information (Damali et al., 2020). If such quality meets customers' value perceptions, they are likely to select services from an honest company and have a superior guest experience (Ahmad et al., 2019). As the disclosure of Risk can help customers avert possible dangers, such level of receptiveness can culminate a positive customer experience. Hence, the third hypothesis is:

\section{H3. Risk assessment by a hotel enhances customers' experiences.}

\subsubsection{Transparency}

Transparency consists of mutual updating of information during interactions for both partners (Prahalad \& Ramaswamy, 2004c). It is also a prerequisite for genuine Dialogue among equal partners (Prahalad \& Ramaswamy, 2004b). Managerial information (e.g., working conditions of hotel employees, implementation of hygiene standards, identities of food suppliers) might appear too irrelevant to share with guests. Still, they are paramount for customers to feel like equal partners and engage in VCC (Kornum \& Mühlbacher, 2013). In their research on the antecedents and implications of VCC behaviour in a hotel setting, Roy et al. (2020) posit that patron fairness perception enhances trust, promoting involvement in VCC behaviours.

The degree of a firm's Transparency indicates the degree of empowerment the firm desires for customers, and the degree of interaction intensity (Tanev et al., 2011). Businesses have traditionally exploited information asymmetry in their marketing communications, reserving particular information about their product components, costs, and profits to avoid 
scrutiny. Transparency seeks to alleviate such asymmetries in communication and promote more openness with customers about internal and external operations of the business (Kim \& Kim, 2016). Firms must understand that Transparency is not always an option because customers may already be aware of certain information, thanks to the ease of information accessibility with the internet (Fan et al., 2019). A low level of perceived asymmetry may increase contentment with the process and motivate more customers to partake in co-creation. Thus, the fourth hypothesis is:

H4. A hotel's transparency enhances customers' experiences.

\subsubsection{Positive experience and satisfaction}

A combination of tourist services and facilities at a specific location comprises the tourism experience (Maunier \& Camelis, 2013). Oh et al. (2007) argue that experience is an essential construct in hospitality and tourism research, defining it as an enjoyable, engaging, and memorable encounter. For a hotel to provide a positive experience, the services should be impeccable (Qian et al., 2021). However, the meaning of "exceptional" differs for each customer as the experience of a tourist is "the subjective mental state felt by participants" (Otto $\&$ Ritchie, 1996, p. 166). Personalization and deep engagement between a hotel and its guests are essential for a positive customer experience.

Adhikari and Bhattacharya (2016) conducted a review of tourism consumer experiences distinguishing two fields of study: (1) experience as a product and (2) sensory interaction. In a Service-Dominant Logic (SDL) context, it is more accurate that customer satisfaction centres on the evaluation of experiences through interactions with several service areas (Xiang et al., 2015). Zhang et al. (2018, p. 52) further this, by suggesting that "value is an interactive consumption experience". Some researchers have studied the direct consequence of VCC on satisfaction (Prebensen \& Xie, 2017), particularly regarding loyalty (Mathis et al., 2016; Polo Peña et al., 2014; Prebensen \& Xie, 2017). However, little empirical evidence relates to tourists' VCC with travel experiences (Mathis et al., 2016). Wu and Gao (2019) identified cocreation behaviours that enhance positive emotional experiences of luxury hotel guests in Ireland by observing their reviews on TripAdvisor. It is plausible that consumer VCC, and specifically DART, has indirect effects on satisfaction through customers' positive experiences.

Superior and quality customer experiences are essential to customer contentment (Jaakola et al., 2015) since "guest satisfaction can be seen as the guest's evaluation of his/her experience through interaction with various service areas" (Xiang et al., 2015, p. 122). Positive experiences are a prerequisite for customer satisfaction (Serra-Cantallops et al., 2020) and occur when the customer's expectations of goods or services are met (Oliver, 1997). Lei et al. (2019) reveal the impact of monitoring multisensory experiences of customer satisfaction in the hotel setting, analyzing the customer reviews on TripAdvisor.com.

Using customer reviews from Expedia.com as representative of hotel guests' experiences, Xiang et al. (2015) assessed whether such experiences affect guest satisfaction. Results suggest a strong, positive relationship between positive experiences and satisfaction. Consequently:

H5. Positive customer experiences relate positively to customer satisfaction.

Figure 1 summarises the current research model and hypothesis. 


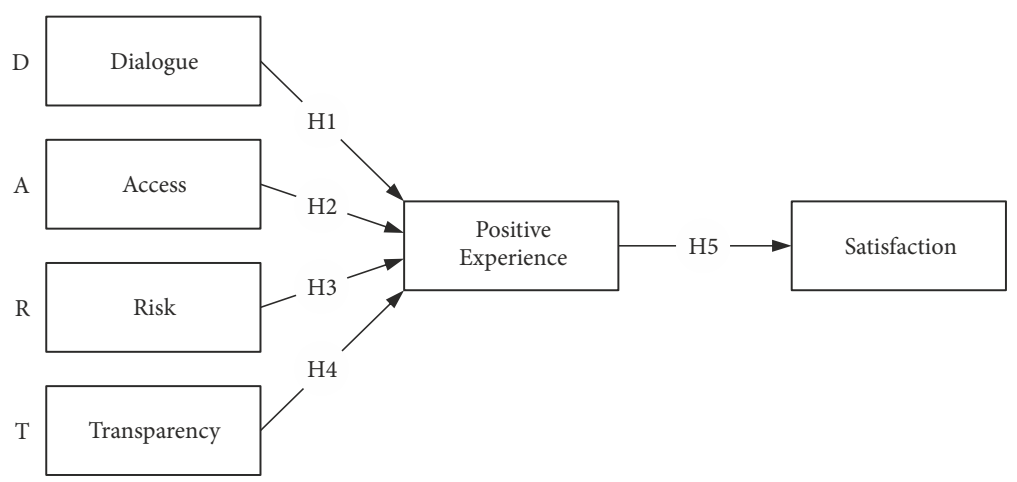

Figure 1. Research model

\section{Methodology}

Based on previous research (Barrera \& Carrión, 2014; Lowry \& Gaskin, 2014) Covariance Based Structural Equation Modelling (SEM) was chosen as the statistical technic. Due to the fact that (1) the research variables are reflective, (2) our research aims to confirm if the DART components, a business-based model, could be applied to customer context, and (3) the sample's study comprises more than 400 cases. AMOS v22 was used for the statistical analysis.

Covariance Based SEM provides an understanding of correlation patterns among the four components of the DART model, based on the consumer's positive experience and whether the latter impacts customer satisfaction.

First, the DART model must be measured. In total, sixteen items were utilized from Albinsson et al. (2016), Taghizadeh et al. (2016) and Mazur and Zaborek (2014) concerning the constructs of Access, Dialogue, Risk, and Transparency. The items for the DART model were adapted to the customer's perspective since they were originally firm-oriented. Secondly, to measure positive experiences, various VCC literature on moments of truth were utilized, and four items were developed accordingly (Chathoth et al., 2013; Xiang et al., 2015). Thirdly, the research of Grissemann and Stokburger-Sauer (2012) on satisfaction provided four items.

Ultimately, 24 items measured six constructs (see Table 2), assessed using a five-point Likert scale that ranged from "totally disagree" (1) to "totally agree" (5).

\subsection{Data and sampling}

A two-part questionnaire was designed. The first was concerned with demographics, while the second consisted of twenty-four measurement items. A pilot study was conducted at the International Airport of Thessaloniki to avoid problems during data collection. The survey resulted in 44 questionnaires being submitted in a single day, an adequate number for a pilot study (Bhattacherjee, 2012). The respondents had no issue understanding the questions and completing the questionnaire at the designated time. The data were also used to test the validity and reliability of the model. The pilot study did not reveal any significant concerns. 
The main survey was conducted at the International Airport of Athens and Corfu. One hundred and fifty-eight responses were collected in Athens in three days, and three hundred and thirty in Corfu over four days, resulting in a total of four hundred and eighty-three usable questionnaires following the convenience sampling technique. This non-probability sampling technique allowed the readily available part of the population that was of interest to be surveyed (Bhattacherjee, 2012).

The sample constituted of persons that were airport travelers on their return flight, understood English, and had previously stayed at a hotel. Travelers were asked to indicate the hotel's stars and fill in the questionnaire based on their experience at the specific hotel. To maintain efficiency, access was granted to the departure area after security control, where the self-administered questionnaires were distributed. The passengers at this stage were more relaxed since they had passed security control and had at least two hours before their departure. Apart from a couple of stores, the lounge area at the Corfu airport does not offer anything else they may have posed a distraction. Thus, the questionnaire was seen as an opportunity for the respondents to chat and pass the time. The questionnaires were printed and attached to clipboards, and distributed within the lounge area for each gate by two researchers (from the first flight to the last).

\subsection{Demographic data}

Among the respondents, 53\% were male and $47 \%$ were female. Ages ranged from 14 to 24 years $(17 \%$ of the sample), 25 to 34 (25\%), 35 to 49 (24\%), 50 to $64(25 \%)$, and 65 and older (9\%). Most travelers held a postgraduate degree (42\%). Nearly half of respondents were UK citizens, followed by Germans (10\%). Most travelled as a family (47\%) and stayed in a 4 -star hotel (44\%). The remainder was divided equally at 3-star hotels (28\%) and 5-star hotels (28\%). Most respondents were leisure travelers $(74 \%)$, followed by business travelers (7\%), and health travelers (4\%) (see Table 1).

Table 1. Respondents' demographics

\begin{tabular}{|c|c|c|}
\hline Gender & $\mathrm{N}$ & $\%$ \\
\hline Male & 225 & 53 \\
\hline Female & 258 & 47 \\
\hline Age & $\mathrm{N}$ & $\%$ \\
\hline $18-24$ & 82 & 17 \\
\hline $25-34$ & 119 & 25 \\
\hline $35-49$ & 118 & 24 \\
\hline $50-64$ & 121 & 25 \\
\hline 65 or above & 42 & 9 \\
\hline Education & $\mathrm{N}$ & $\%$ \\
\hline Primary & 23 & 5 \\
\hline Secondary & 116 & 26 \\
\hline Tertiary & 137 & 28 \\
\hline Postgraduate & 205 & 42 \\
\hline Hotel star's & $\mathrm{N}$ & $\%$ \\
\hline 3 stars & 135 & 28 \\
\hline 4 stars & 215 & 44 \\
\hline 5 stars & 133 & 28 \\
\hline Type of trip & $\mathrm{N}$ & $\%$ \\
\hline Single & 49 & 10 \\
\hline Family & 225 & 47 \\
\hline Other & 198 & 41 \\
\hline Reason for travel & $\mathrm{N}$ & $\%$ \\
\hline Business & 33 & 7 \\
\hline Leisure & 356 & 74 \\
\hline Health & 20 & 4 \\
\hline Other & 63 & 13 \\
\hline Country* & $\mathrm{N}$ & $\%$ \\
\hline Germany & 48 & 10 \\
\hline England & 240 & 50 \\
\hline Greece & 26 & 5 \\
\hline Poland & 26 & 5 \\
\hline Other & 144 & 30 \\
\hline
\end{tabular}




\section{Analysis of results}

Before testing the hypothesis, the constructs were assessed for validity and reliability using the Confirmatory Factor Analysis (CFA). Regarding construct validity, Table 2 shows that values obtained exceeded the threshold of 0.70 for confirmatory research, and 0.40 for exploratory studies, as is this case (Hair et al., 2010). By using the Average Variance Extracted (AVE) and Composite Reliability (CR), the convergent validity of the model was evaluated (Fornell \& Larcker, 1981). The acceptance values are above 0.5 and 0.7 for AVE and CR, respectively (Fornell \& Larcker, 1981). All construct values exceeded the rates mentioned above (see Table 3). Cronbach's alpha and composite reliability was utilized to evaluate the coefficient and internal consistency (Bhattacherjee, 2012). For the components of the DART model, the values exceeded 0.7 .

Concerning discriminant validity (DV) of the model, the results (see Table 4) indicate that each variable is different from the other, therefore DV also exists. Descriptive statistics and an assessment of normality for every construct's item were provided (see Table 4). Their normality was evaluated by using both Kurtosis and Skewness' critical region (cr). The whole indicators show values lower than the set criteria of 1.0 for Kurtosis and Skewness. Concerning CR, the values obtained do not surpass the limit of 8.0; in fact, the value higher of CR is of 6.13.

Firstly, and before moving forward to the SEM-measure model analysis in detail, we must ensure that the study's data is adequate to the research model (Figure 1). Following previous research (Guerrero et al., 2015; Mahmoud et al., 2020), 4 indicators were used to evaluate this matter: chi-square to the number of degrees of freedom (v2/df), CFI, RMSEA, and PCLOSE. The results (see Table 2) indicated that our data is evacuated to assess our hypothesis. Second, in most studies, it is considered crucial to evaluate if the study might have a typical problem: common bias (CB). Traditionally academics have used Podsakoff et al. (2003) and Harman's test as possible remedies to solve the CB problem. According to Lowry and Gaskin (2014), those technics are outdated and cannot detect CB. However, there currently exists a tool that is more accurate in validating CB; the Specific Bias Tests (SBT) developed by Gaskin and Lim (2017) SBT allow one to determine if bias response exists (null hypothesis); in other words, if a research model's research could be affected by CB. In our case (since we know which variables might affect the results), we performed two SBT; one per each variable (see Table 5). The results indicated that it was not possible to detect CB. Thus, it is possible to continue with the following SEM analysis.

CFA and the structural model (SM) were estimated using AMOS v24 and SPSS 22 for calculating the correlations significances (i.e, DV). In order to avoid the lack of non-normality distribution study (Efron \& Tibshirani, 1986) and to determine the statistical significance of the parameters, the bootstrapping bias-corrected test was used. Such a procedure with SEM-AMOS is gaining broad acceptance in both the psychology (Mahmoud et al., 2020) and business landscape (Malca et al., 2020). The results can be seen in Table 6. Additionally, we present the standardized direct, indirect, and total effects as measures of the so-called effect size (Cohen, 1988). These indicators allow us to pinpoint the role mediator that Access (0.18) and Transparency (0.35) may have on satisfaction throughout the positive experience (further on this Table 7). We must be clear that our research is not focused on the mediation model; therefore, it does not matter in this research. As Lachowicz et al. (2018) have established, the effect size is crucial to conduct an evaluation when the research aims to quantify the mediation variables' effect. 
Table 2. Constructs and results and CFA

\begin{tabular}{|c|c|c|c|c|c|c|c|c|c|}
\hline CODE & \multicolumn{5}{|c|}{ Variables } & $\mathrm{L}$ & a & AVE & $\mathrm{R}$ \\
\hline \multicolumn{6}{|c|}{ Dialogue with hotel } & & 0.846 & 0.592 & 0.851 \\
\hline D1 & \multicolumn{5}{|c|}{ Active dialogue with staff } & 0.715 & & & \\
\hline D2 & \multicolumn{5}{|c|}{ Encouraged to express thoughts } & 0.890 & & & \\
\hline D3 & \multicolumn{5}{|c|}{ Opportunity to share ideas } & 0.819 & & & \\
\hline D4 & \multicolumn{5}{|c|}{ Use of different communication channels } & 0.629 & & & \\
\hline \multicolumn{6}{|c|}{ Access to hotel } & & 0.873 & 0.657 & 0.882 \\
\hline A1 & \multicolumn{5}{|c|}{ I had the ability to determine how to be serviced } & 0.878 & & & \\
\hline A2 & \multicolumn{5}{|c|}{ I had many choices on how to experience the service } & 0.893 & & & \\
\hline A3 & \multicolumn{5}{|c|}{$\begin{array}{l}\text { I had the ability to determine the time, the place and how } \\
\text { to receive the service }\end{array}$} & 0.848 & & & \\
\hline A4 & \multicolumn{5}{|c|}{$\begin{array}{l}\text { I had the ability to engage in the configuration of the } \\
\text { service }\end{array}$} & 0.585 & & & \\
\hline \multicolumn{6}{|c|}{ Risk with hotel } & & 0.883 & 0.661 & 0.886 \\
\hline R1 & \multicolumn{5}{|c|}{$\begin{array}{l}\text { I was made aware by the hotel of possible risks and benefits } \\
\text { for using their services }\end{array}$} & 0.805 & & & \\
\hline R2 & \multicolumn{5}{|c|}{$\begin{array}{l}\text { I could gather information on possible risks and benefits } \\
\text { from using hotels services }\end{array}$} & 0.862 & & & \\
\hline R3 & \multicolumn{5}{|c|}{$\begin{array}{l}\text { The hotel provided accurate and actual information on the } \\
\text { pros and cons of the services }\end{array}$} & 0.827 & & & \\
\hline $\mathrm{R} 4$ & \multicolumn{5}{|c|}{ I was given advises on how to use hotel services } & 0.755 & & & \\
\hline \multicolumn{6}{|c|}{ Transparency } & & 0.829 & 0.627 & 0.883 \\
\hline $\mathrm{T} 1$ & \multicolumn{5}{|c|}{$\begin{array}{l}\text { I had all the information needed to improve the outcomes } \\
\text { of the service experience }\end{array}$} & 0.865 & & & \\
\hline $\mathrm{T} 2$ & \multicolumn{5}{|c|}{$\begin{array}{l}\text { I had open access to information to enhance the overall } \\
\text { service experience }\end{array}$} & 0.828 & & & \\
\hline T3 & \multicolumn{5}{|c|}{ All the information provided by the hotel was updated } & 0.669 & & & \\
\hline \multicolumn{6}{|c|}{ Positive experience } & & 0.854 & 0.665 & 0.856 \\
\hline PE1 & \multicolumn{5}{|c|}{ My experience with the room service was positive } & 0.841 & & & \\
\hline PE2 & \multicolumn{5}{|c|}{ My experience with the reception was positive } & 0.859 & & & \\
\hline PE3 & \multicolumn{5}{|c|}{ My experience with the hotel staff was positive } & 0.741 & & & \\
\hline \multicolumn{6}{|c|}{ Satisfaction } & & 0.946 & 0.817 & 0.947 \\
\hline S1 & \multicolumn{5}{|c|}{ Satisfied with the customer service } & 0.885 & & & \\
\hline S2 & \multicolumn{5}{|c|}{ My stay at this hotel has met my expectations } & 0.902 & & & \\
\hline S3 & \multicolumn{5}{|c|}{ My interaction with the hotel was satisfactory } & 0.923 & & & \\
\hline S4 & I was $\mathrm{s}$ & tisfied with the hotel & & & & 0.905 & & & \\
\hline & & & $\mathrm{Cl}$ & & & & & & \\
\hline Mod & el fit & $\mathrm{Chi}^{2} / \mathrm{df}$ & RMSEA & PCLOSE & GFI & AGFI & CFI & TLI & NFI \\
\hline Results & & $2.426(458.430 / 189)$ & 0.054 & 0.127 & 0.920 & 0.822 & 0.967 & 0.960 & 0.946 \\
\hline Recomn & nended & $1-3$ & $<0.8$ & $<0.5$ & $0-1$ & $0-1$ & $0-1$ & $0-1$ & $0-1$ \\
\hline
\end{tabular}

Note: $\mathrm{L}=$ loadings; $\mathrm{a}=$ Cronhach's alpha coefficient (SPSS 22); $\mathrm{R}=$ composite reliability. 
Table 3. SEM's discriminant validity

\begin{tabular}{|c|c|c|c|c|c|c|}
\hline Construct & Dialogue & Access & Risk & Transparency & Satisfaction & Positive-Experience \\
\hline Dialogue & 0.760 & & & & & \\
\hline Access & $0.521^{\star \star}$ & 0.810 & & & & \\
\hline Risk & $0.497^{\star \star}$ & $0.526^{\star \star}$ & 0.813 & & & \\
\hline Transparency & $0.484^{\star \star}$ & $0.517^{\star \star}$ & $0.553^{\star \star}$ & 0.791 & & \\
\hline Satisfaction & $0.323^{\star \star}$ & $0.498^{\star \star}$ & $0.470^{\star \star}$ & $0.501^{\star \star}$ & 0.904 & \\
\hline Posit-Experience & $0.357^{\star \star}$ & $0.436^{\star *}$ & $0.488^{\star \star}$ & $0.483^{\star \star}$ & $0.702^{\star \star}$ & 0.815 \\
\hline
\end{tabular}

Note: The bold figures are the square root of the AVE. The normal figures are correlations between variables. ${ }^{*}$ Significant at the 0.01 level (2-tailed). SPSS v.22.

Table 4. Descriptive statistics and normality assessment

\begin{tabular}{|c|c|c|c|c|c|c|}
\hline Variable & Mean & SD & Skewness & c.r. & kurtosis & c.r. \\
\hline S4 & 4.17 & 0.977 & -1.188 & -10.670 & 0.993 & 4.461 \\
\hline S3 & 4.12 & 1.017 & -1.100 & -9.882 & 0.615 & 2.761 \\
\hline S2 & 4.03 & 1.081 & -1.054 & -9.467 & 0.432 & 1.940 \\
\hline S1 & 4.12 & 1.054 & -1.164 & -10.457 & 0.726 & 3261 \\
\hline PE3 & 4.26 & 1.014 & -1.433 & -12.872 & 1350 & 6.959 \\
\hline PE2 & 4.16 & 1.075 & -1.327 & -11.923 & 1.126 & 5.058 \\
\hline PE1 & 3.88 & 1218 & -0.903 & -8.106 & -0.117 & -327 \\
\hline T3 & 3.80 & 1211 & -0.837 & -7.520 & -200 & -0.899 \\
\hline T2 & 3.24 & 1225 & -254 & -2285 & -0.788 & -3.541 \\
\hline T1 & 3.40 & 1280 & -398 & -3.572 & -0.856 & -3.842 \\
\hline R4 & 3.19 & 1376 & -222 & $-1.9 \%$ & -1.156 & -5.193 \\
\hline R3 & 3.23 & 1289 & -269 & -2.417 & -0.977 & 4.386 \\
\hline R2 & 3.24 & 1278 & -265 & -2.376 & -0.952 & 4276 \\
\hline R1 & 3.40 & 1269 & -0.429 & -3.855 & -0.817 & -3.667 \\
\hline A4 & 2.62 & 1383 & 0.326 & 2.929 & -1.120 & -5.031 \\
\hline A3 & 3.39 & 1290 & -0.479 & 4.304 & -0.786 & -3.531 \\
\hline A2 & 3.37 & 1234 & -0.426 & -3.826 & -0.736 & -3.306 \\
\hline A1 & 3.39 & 1347 & -0.410 & -3.680 & -0.943 & 4234 \\
\hline D4 & 2.67 & 1.460 & 254 & 2277 & -1281 & -5.753 \\
\hline D3 & 2.95 & 1.469 & 0.001 & 0.008 & -1.333 & -5.987 \\
\hline D2 & 3.03 & 1.462 & -0.077 & -0.696 & -1.335 & -5.995 \\
\hline D1 & 2.96 & 1307 & -0.047 & -0.420 & -1.406 & -6.312 \\
\hline Multivariate & & & & & 149309 & 50.609 \\
\hline Th & & & & & \\
\hline
\end{tabular}

Notes: The answers range $\min =1$ to $\max =5$, c.r. $=$ critical region. 
Table 5. Specific Bias Tests

\begin{tabular}{|l|c|c|c|c|}
\hline \multicolumn{5}{|c|}{ Specific Bias Tests: Positive experience } \\
\hline Zero Constraints Test & $\mathrm{X}^{2}$ & $\mathrm{DF}$ & Delta & $\mathrm{p}$-value \\
\hline Unconstrained Model & 1124.000 & 509 & $\begin{array}{l}\mathrm{X}^{2}=183,000 \\
\mathrm{DF}=415\end{array}$ & 1.000 \\
\hline \multicolumn{7}{|c|}{ Specific Bias Tests: Satisfaction } \\
\hline Zero Constraints Test & $\mathrm{X}^{2}$ & $\mathrm{DF}$ & Delta & p-value \\
\hline Unconstrained Model & 575.000 & 187 & $\begin{array}{l}\mathrm{X}^{2}=587,000 \\
\mathrm{DF}=562\end{array}$ & 0.225 \\
\hline
\end{tabular}

Table 6. SEM-results and null-hypothesis significance

\begin{tabular}{|c|c|c|c|c|c|c|c|c|c|}
\hline \multirow[t]{2}{*}{ Hypotheses } & & \multicolumn{3}{|c|}{$N=484$} & \multicolumn{5}{|c|}{$\begin{array}{l}\text { Bias-corrected Bootstrap } \\
1000 \text { subsamples CI 95\% }\end{array}$} \\
\hline & $\mathrm{R}^{2}$ & Estimate & S.E. & Sig & $\begin{array}{l}\text { Esti- } \\
\text { mate }\end{array}$ & Lower & Upper & $\begin{array}{l}\text { Sig/ } \\
\text { Sup. }\end{array}$ & $\begin{array}{l}\text { Hypotheses } \\
\text { validation }\end{array}$ \\
\hline $\begin{array}{l}(\mathrm{H} 1) \text { Dialogue } \rightarrow \text { Positive } \\
\text { Experience }\end{array}$ & \multirow{4}{*}{0.48} & -0.003 & 0.044 & 0.938 & -0.003 & -0.101 & 0.093 & 1.000 & No-Supp. \\
\hline $\begin{array}{l}(\mathrm{H} 2) \text { Access } \rightarrow \text { Positive } \\
\text { Experience }\end{array}$ & & 0.166 & 0.046 & $* * *$ & 0.166 & 0.061 & 0.285 & 0.004 & Supported \\
\hline $\begin{array}{l}\text { (H3) Risk } \rightarrow \text { Positive } \\
\text { Experience }\end{array}$ & & 0.135 & 0.066 & 0.041 & 0.135 & -0.061 & 0.312 & $0.123^{\mathrm{NS}}$ & No-Supp. \\
\hline $\begin{array}{l}(\mathrm{H} 4) \text { Transparency } \rightarrow \\
\text { Positive Experience }\end{array}$ & & 0.343 & 0.082 & $* * *$ & 0.343 & 0.135 & 0.607 & $0.005^{\mathrm{Y}}$ & Supported \\
\hline $\begin{array}{l}\text { (H5) Satisfaction } \rightarrow \text { Positive } \\
\text { Experience }\end{array}$ & 0.82 & 0.937 & 0.052 & $* * *$ & 0.937 & 0.831 & 1.051 & $0.001^{\mathrm{Y}}$ & Supported \\
\hline Model fit & \multicolumn{2}{|c|}{$\mathrm{Chi}^{2} / \mathrm{df}$} & RMSEA & PCLOSE & GFI & AGFI & CFI & TLI & NFI \\
\hline Results & \multicolumn{2}{|c|}{$2.53(487,321 / 192)$} & 0.056 & 0.044 & 0.917 & 0.890 & 0.964 & 0.957 & 0.783 \\
\hline Recommended & \multicolumn{2}{|c|}{$1-3$} & $<0.8$ & $<0.5$ & $0-1$ & $0-1$ & $0-1$ & $0-1$ & $0-1$ \\
\hline
\end{tabular}

Notes: NS non-supported; yes.

Table 7. Relationship effects

\begin{tabular}{|c|c|c|c|c|c|c|}
\hline \multicolumn{7}{|c|}{ Standardized indirect effects } \\
\hline & Transp & Risk & Access & Dialogue & Positive & Satisfac \\
\hline \multicolumn{7}{|l|}{ Positive } \\
\hline Satisfac & 0.35 & 0.145 & 0.198 & -0.004 & & \\
\hline \multicolumn{7}{|c|}{ Standardized direct effects } \\
\hline & Transp & Risk & Access & Dialogue & Positive & Satisfac \\
\hline Positive & 0.385 & 0.159 & 0.218 & -0.005 & & \\
\hline Satisfac & & & & & 0.907 & \\
\hline \multicolumn{7}{|c|}{ Total effects } \\
\hline & Transp & Risk & Access & Dialogue & Positive & Satisfac \\
\hline Positive & 0.343 & 0.135 & 0.166 & -0.003 & 0 & 0 \\
\hline Satisfac & 0.321 & 0.126 & 0.156 & -0.003 & 0.937 & 0 \\
\hline
\end{tabular}


Dimensions of DART were assessed concerning positive experiences, and this was assessed simultaneously regarding satisfaction (see Table 5). Utilizing indices from the three categories of model fit, the suitability of the model was evaluated (Hair et al., 2010). Regarding absolute fit, results suggested a good fit, with a GFI of 0.917 (an acceptable value is 0.9 (Jöreskog \& Sörbom, 1984), and an RMSEA of 0.056 (an acceptable value is less than 0.08; Browne \& Robert, 1993). Concerning incremental fit, CFI and TLI were above 0.9, which is adequate (Browne \& Robert, 1993). Concerning parsimonious fit, chi-squared/df was 2.53, within the acceptable range of less than 3.0 (Marsh \& Hocevar, 1985). Table 6 summarizes the structural model results.

The outcomes of the SEM analysis suggest that components of the DART model affected positive experiences only partially. Contradictory of the expectation, Dialogue $(\beta=-0.03$, $p=0.938)$ and Risk $(\beta=0.135, p=0.041)$ effects are not significant to the positive experiences of guests, thus $\mathrm{H} 1$ and $\mathrm{H} 2$ are not supported. Seeing that the hypothesis that suggested positive effects of Access $\left(\beta=0.168^{\star * *}\right)$, and Transparency $\left(\beta=0.349^{\star * *}\right)$ was realized, H3 and $\mathrm{H} 4$ are both indeed supported. The results also reveal the existence of a strong relationship between Positive Experiences and Satisfaction $\left(\beta=0.937^{\star * *}\right)$, supporting H5.

\section{Discussion}

The findings indicated that not all DART components lead to positive experiences for hotel clients. Dialogue and Risk did not contribute to positive guest experiences, contradictory to Access and Transparency. Based on the study, it was revealed that a robust relationship exists between positive experiences and satisfaction in the hotel context.

In our results, we see a paradox where Dialogue and Risk assessment do not positively impact the hotel guest's experience while, in general, VCC is about positive experiences. The explanation might rely on the nature of the traditional hotel industry and, more specifically, the nature of the resort hotels and the sample composition (since $69 \%$ of the questionnaires were collected in Corfu). Foreign tourists commonly travel to Corfu for leisure (78\%), and purchases are made from major European tour operators (including packages with all expenses paid). Zouni and Kouremenos (2008) argue that tour operators encourage customers to interact and contribute in the vacation process from the design to the consumption, meaning that tourists' trips are pre-arranged, and the potential for Dialogue with hotels occurs with travel agents before departure.

The failure in communication could very well result from actions triggered by either the hotels or customer, as each actor has a unique perception of the actions and behaviour required for a positive outcome (Vafeas et al., 2016). Thus, ineffective and problematic communication may be related to conventional hotels' background (especially to seaside resorts) where the guest's main goal is to relax. In such cases, according to Neuhofer (2016), technology-based Dialogue is possible to lead to negative tourism experiences as tourists also seek a "digital detox" in addition to their "work routine detox." Furthermore, during guests' stays, most communication revolves around new issues, allowing engagement to occur with tour operators prior to their stay (Wang et al., 2000). Communication with hotel staff often concerns emergencies such as malfunctioning air conditioning or poor WIFI signals; hence 
contact with the hotel is usually associated with something negative, implying that accommodations and services were not as a tour operator had implied.

Lastly, Dialogue failure may lie in the antecedents of value diminution (Vafeas et al., 2016), such as inadequate human capital from the perspective of the hotel and the customer. Hotel staff may not have the ability or knowledge to reciprocate customer communication, and customers may not have the attitude or skill to engage in meaningful Dialogue with hotel staff. This may mean that every attempt to communicate could be useless in provoking a deep engagement.

The nature of the resort hotels and our sample composition might also be the case to explain how Risk does not affect the positive experience. Communicating possible risks to resort hotel guests that the tour operator did not, might explain why it is not contributing to a positive experience. Unveiling a potential risk to a customer that has already spend a significant amount of money to relax when they were under the impression that there were no risks will inevitably lead to negative associations, despite the fact that hotel staff informed them in good faith. An example would be a receptionist informing a guest about loud, stray dogs outside the hotel at midnight, or a possible spider issue in their bungalow. Resort hotel customers would like to assess potential dangers and threats before their hotel stay rather than during, as such information can affect their purchasing decision. Often, tourists do not want to be receiving risk information while on holiday (Aliperti et al., 2020).

On the other hand, Access and Transparency positively affect customers' experiences in a hotel context. Relevant research on whether Access or Transparency can affect the positive experiences of hotel customers does not exist. Buhalis and Sinarta (2019) state that the symmetry of information is essential for both sides, and that information must be exchanged and accessed to co-create value.

Another explanation for the DART model's partial effect on hotel guests' positive experience is the possibility of indirect relationships based on the Dialogue and Risk components. In this sense, these two pillars can affect or be affected by the other two parts (Transparency and Access). As Albinsson et al. (2016) have indicated, the DART model components are co-dependent conditions in creating an organizational climate conducive to strategic VCC. Furthermore, these authors add, "Dialogue is critical but meaningful, the genuine exchange cannot occur in the absence of access or transparency" (Albinsson et al., 2016, p. 44). Similarly, these last two components can evaluate the risks associated with the hotels' products and services. Therefore, the DART model's two main dimensions - from a consumer perspective - would be Access and Transparency. Perhaps, the other two components can be understood more directly from a hotel's perspective. Thus, the hotel industry's VCC strategy should emphasize and expand upon the blocks of Access and Transparency to favor the positive customer experience.

Lastly, our results highlight a robust relationship between positive experiences and satisfaction, supported by hotel literature (Serra-Cantallops et al., 2020; Xiang et al., 2015). 


\section{Conclusions}

This study contributes to the theoretical and methodological advancements of VCC in tourism and hotel research. DART is used to investigate the dynamics of VCC, and whether engagement and involvement by customers with a hotel and its products will generate positive experiences and satisfaction. VCC embeds experiences, and the more positive the experiences are for customers, the more satisfied they are with a hotel.

The results are interesting as the four pillars of interaction of the DART model only partially affect hotel customers positive experience. Surprisingly, Access and Transparency affect the positive experiences of hotel guests in contrast to Dialogue and Risk, which can be explained through the traditional hotel context and the sample composition of our research. It is apparent now, that our research reinforces the argument stating positive experiences are the key to satisfied hotel customers.

The uniqueness of this research resides in the evaluation of the DART model in a traditional hospitality context and in the analysis of the model from a customer's approach. This study may very well be one of the first that invalidates and tests the DART model from a customer standpoint among hotel guests offering valuable insights and a better understanding of the VCC mechanism, as in VCC, all actors involved are equal. The model reflection assists in further refining the DART model as a framework for VCC. Thus, the current study enriches and consolidates VCC-DART theory.

There are several implications to consider as the customer viewpoint approach of the DART model can enhance hotel managers' perception of the VCC process. Such knowledge can be utilized to redesign or adjust hotel services and operations, providing an improved framework for customers to co-create. VCC strategies require hotels to use experience-centric logic, in which each interaction with a customer contributes to positive experiences and therefore, a satisfied customer. Although DART is flexible, allowing firms to use combinations of the four building blocks of interaction, this study suggests that Access and Transparency influence customers' positive experiences. It is a prerequisite for customers to trust a firm and have access to hotel services.

Increasing Transparency in every aspect of hotel management enables the opportunity to build credibility, a necessary element for VCC. Hotel managers should evade the cloudiness of the cost of services, providing all the information needed for the best outcome of their services. Adopting and applying a transparent policy concerning fees and services would help to build trust with their customers, and create positive experiences leading to customer satisfaction. Such policies could entail well defined credit card processing fees, sticking to the quoted room price, no hidden resort fees or service fees, and no deceptive service offerings.

VCC strategies indicate that hotel managers should invest in technologies that allow customers to make informative decisions on how, when, and where to receive hotel services. However, especially for resort hotels, investments should be discreet and carefully designed, taking into consideration the need for tourists to escape from routine and technology. For example, through the option of an application or a traditional breakfast card, hotel guests can personalize their breakfast, choose where to have their breakfast (e.g.in their room or in 
the restaurant), and also to choose the time. The same could apply for check in and check out procedures, and many different aspects of hotel service offering.

For customers to engage in a meaningful Dialogue, VCC strategy must be implemented from the grassroots. Hotels must embrace an active engagement policy to develop mechanisms that collect and analyze valuable data from the hotel ecosystem to learn, anticipate, and react to customer needs. These mechanisms should involve multiple channels, whether digital (apps, social media and POS) and/or non-digital, such as employees and paper questionnaires, from multiple sources. For example, an app that provides access to hotel services could also be used as a tracking mechanism regarding the usage frequency of the service and its features. The data derived from the interaction between the service and the customer could assist in developing and introducing customized services and customer contemplation.

However, some study limitations should be acknowledged. This research uses a sample of tourists that had already stayed in hotels. Other situations should be analyzed to assess disparities at different moments during a customer's experience. Researchers could then analyze how customers interact with hotel employees in different phases.

Another limitation is the context of traditional hotels, especially seaside resorts, at which guests seek time off from their routines to relax. Researchers should consider a variety of factors such as accommodation types, types of guests, where the tourist has come from, the caliber of their air transportation, tourist attractions available, car rentals, and so on.

Combinations of the four dimensions of DART and their effects on other constructs, such as quality of service, brand image, and customer loyalty, should be examined in future studies.

An additional limitation of our research is its cross-sectional nature. Currently, with the consequences of the pandemic we are facing, tourist perceptions of satisfaction and experiences with hotels have most likely changed. Going forward, the effects that a global crisis may pose should be considered since new research could reveal if tourists' perceptions over time have changed.

\section{Author contributions}

JPV demarcated the research problem, literature review and formulated hypothesis and made the statistical analysis with AMOS. KS wrote the first draft of the article. JMLB defined the study variables, wrote the qualitative analysis, and he has re-written the manuscript. LFAQ definition of methodological procedures and second revision of the document and improvements of the literature review.

\section{References}

Adhikari, A., \& Bhattacharya, S. (2016). Appraisal of literature on customer experience in tourism sector: review and framework. Current Issues in Tourism, 19(4), 296-321. https://doi.org/10.1080/13683500.2015.1082538

Ahmad, S. Z., Ahmad, N., \& Papastathopoulos, A. (2019). Measuring service quality and customer satisfaction of the small- and medium-sized hotels (SMSHs) industry: Lessons from United Arab Emirates (UAE). Tourism Review, 74(3), 349-370. https://doi.org/10.1108/TR-10-2017-0160 
Albinsson, P. A., Perera, B. Y., \& Sautter, P. T. (2016). DART scale development: Diagnosing a firm's readiness for strategic value co-creation. Journal of Marketing Theory and Practice, 24(1), 42-58. https://doi.org/10.1080/10696679.2016.1089763

Aliperti, G., Nagai, H., \& Cruz, A. M. (2020). Communicating risk to tourists: A mental models approach to identifying gaps and misperceptions. Tourism Management Perspectives, 33, 100615. https://doi.org/10.1016/j.tmp.2019.100615

Barrera, R. B., \& Carrión, G. C. (2014). Simultaneous measurement of quality in different online services. The Service Industries Journal, 34(2), 123-144. https://doi.org/10.1080/02642069.2013.763345

Bhattacherjee, A. (2012). Social science research: principles, methods, and practices. In Textbooks collection (Vol. 9). Global Text Project.

Browne, M. W., \& Robert, C. (1993). Alternative ways of assessing model fit. In K. A. Bollen, \& J. S. Long (Eds.), Testing structural equation models. Sage.

Buhalis, D. (2019). Technology in tourism-from information communication technologies to eTourism and smart tourism towards ambient intelligence tourism: a perspective article. Tourism Review, 75(1), 267-272. https://doi.org/10.1108/TR-06-2019-0258

Buhalis, D., \& Foerste, M. (2014). SoCoMo marketing for travel and tourism: Empowering co-creation of value. Journal of Destination Marketing and Management, 4(3), 151-161. https://doi.org/10.1016/j.jdmm.2015.04.001

Buhalis, D., \& Leung, R. (2018). Smart hospitality - Interconnectivity and interoperability towards an ecosystem. International Journal of Hospitality Management, 71, 41-50. https://doi.org/10.1016/j.ijhm.2017.11.011

Buhalis, D., \& Sinarta, Y. (2019). Real-time co-creation and nowness service: lessons from tourism and hospitality. Journal of Travel and Tourism Marketing, 36(5), 563-582. https://doi.org/10.1080/10548408.2019.1592059

Campos, A. C., Mendes, J., Valle, P. O. do, \& Scott, N. (2018). Co-creation of tourist experiences: a literature review. Current Issues in Tourism, 21(4), 369-400. https://doi.org/10.1080/13683500.2015.1081158

Chathoth, P., Altinay, L., Harrington, R. J., Okumus, F., \& Chan, E. S. W. (2013). Co-production versus co-creation: A process based continuum in the hotel service context. International Journal of Hospitality Management, 32(1), 11-20. https://doi.org/10.1016/j.ijhm.2012.03.009

Chathoth, P., Ungson, G. R., Harrington, R. J., \& Chan, E. S. W. (2016). Co-creation and higher order customer engagement in hospitality and tourism services. International Journal of Contemporary Hospitality Management, 28(2), 222-245. https://doi.org/10.1108/IJCHM-10-2014-0526

Chen, J. S., Kerr, D., Chou, C. Y., \& Ang, C. (2017). Business co-creation for service innovation in the hospitality and tourism industry. International Journal of Contemporary Hospitality Management, 29(6), 1522-1540. https://doi.org/10.1108/IJCHM-06-2015-0308

Cohen, J. (1988). Statistical power analysis for the behavioral sciences (2nd ed.). Lawrence Erlbaum Associates.

Damali, U., Secchi, E., Tax, S. S., \& McCutcheon, D. (2020). Customer participation risk management: conceptual model and managerial assessment tool. Journal of Service Management, 32(1), 27-51. https://doi.org/10.1108/JOSM-05-2018-0147

Efron, B., \& Tibshirani, R. (1986). Bootstrap methods for standard errors, confidence intervals, and other measures of statistical accuracy. Statistical Science, 1(1), 54-75. https://doi.org/10.1214/ss/1177013815

Fan, D. X. F., Buhalis, D., \& Lin, B. (2019). A tourist typology of online and face-to-face social contact: Destination immersion and tourism encapsulation/decapsulation. Annals of Tourism Research, 78, 102757. https://doi.org/10.1016/j.annals.2019.102757 
Femenia-Serra, F., Perles-Ribes, J. F., \& Ivars-Baidal, J. A. (2019). Smart destinations and tech-savvy millennial tourists: hype versus reality. Tourism Review, 74(1), 63-81.

https://doi.org/10.1108/TR-02-2018-0018

Fornell, C., \& Larcker, D. F. (1981). Evaluating structural equation models with unobservable variables and measurement error. Journal of Marketing Research, 18(1), 39.

https://doi.org/10.1177/002224378101800104

Gajdošík, T., Maráková, V., \& Kučerová, J. (2020). From mass tourists to smart tourists: a perspective article. Tourism Review, 76(1), 47-50. https://doi.org/10.1108/TR-07-2019-0285

Gallarza, M. G., \& Gil Saura, I. (2020). Consumer value in tourism: a perspective article. Tourism Review, 75(1), 41-44. https://doi.org/10.1108/TR-06-2019-0227

Galvagno, M., \& Dalli, D. (2014). Theory of value co-creation: a systematic literature review. Managing Service Quality: An International Journal, 24(6), 643-683. https://doi.org/10.1108/MSQ-09-2013-0187

Gaskin, J., \& Lim, J. (2017). Model fit measures (AMOS Plugin, 2016). Gaskination's StatWiki.

González-Mansilla, Ó., Berenguer-Contrí, G., \& Serra-Cantallops, A. (2019). The impact of value cocreation on hotel brand equity and customer satisfaction. Tourism Management, 75, 51-65. https://doi.org/10.1016/j.tourman.2019.04.024

Grissemann, U. S., \& Stokburger-Sauer, N. E. (2012). Customer co-creation of travel services: The role of company support and customer satisfaction with the co-creation performance. Tourism Management, 33(6), 1483-1492. https://doi.org/10.1016/j.tourman.2012.02.002

Grönroos, C. (2004). The relationship marketing process: Communication, interaction, dialogue, value. Journal of Business \& Industrial Marketing, 19, 99-113. https://doi.org/10.1108/08858620410523981

Guerrero, M., Cunningham, J. A., \& Urbano, D. (2015). Economic impact of entrepreneurial universities' activities: An exploratory study of the United Kingdom. Research Policy, 44(3), 748-764. https://doi.org/10.1016/j.respol.2014.10.008

Hair, J. F., Anderson, R. E., \& Tatham, R. (2010). Multivariate data analysis. Prentice Hall.

Heidenreich, S., Wittkowski, K., Handrich, M., \& Falk, T. (2015). The dark side of customer co-creation: exploring the consequences of failed co-created services. Journal of the Academy of Marketing Science, 43(3), 279-296. https://doi.org/10.1007/s11747-014-0387-4

Huang, Y. C., Chang, L. L., Yu, C. P., \& Chen, J. (2019). Examining an extended technology acceptance model with experience construct on hotel consumers' adoption of mobile applications. Journal of Hospitality Marketing and Management, 28(8), 957-980. https://doi.org/10.1080/19368623.2019.1580172

Ingram, C., Caruana, R., \& McCabe, S. (2017). PARTicipative inquiry for tourist experience. Annals of Tourism Research, 65, 13-24. https://doi.org/10.1016/j.annals.2017.04.008

Jaakola, E., Helkkula, A., \& Aarika. (2015). Service experience co-creation: conceptualization, implications, and future research directions. Journal of Service Management, 26(2), 182-205. https://doi.org/10.1108/JOSM-12-2014-0323

Jöreskog, K. G., \& Sörbom, D. (1984). LISREL VI, analysis of linear structural relationships by maximum likelihood, instrumental variables, and least squares methods. Scientific Software.

Kim, S.-B., \& Kim, D.-Y. (2016). The impacts of corporate social responsibility, service quality, and transparency on relationship quality and customer loyalty in the hotel industry. Asian Journal of Sustainability and Social Responsibility, 1(1), 39-55. https://doi.org/10.1186/s41180-016-0004-1

Kornum, N., \& Mühlbacher, H. (2013). Multi-stakeholder virtual dialogue: Introduction to the special issue. Journal of Business Research, 66(9), 1460-1464. https://doi.org/10.1016/j.jbusres.2012.09.008

Kuo, P. J., Zhang, L., \& Cranage, D. A. (2015). What you get is not what you saw: Exploring the impacts of misleading hotel website photos. International Journal of Contemporary Hospitality Management, 27(6), 1301-1319. https://doi.org/10.1108/IJCHM-11-2013-0532 
Lachowicz, M. J., Preacher, K. J., \& Kelley, K. (2018). A novel measure of effect size for mediation analysis. Psychological Methods, 23(2), 244-261. https://doi.org/10.1037/met0000165

Lazarus, D., Krishna, A., \& Dhaka, S. (2014). Co-creation willingness matrix and capability continuum for classification and scaling of services. Journal of Global Marketing, 27(4), 213-225. https://doi.org/10.1080/08911762.2014.909551

Lowry, P. B., \& Gaskin, J. (2014). Partial least squares (PLS) structural equation modeling (SEM) for building and testing behavioral causal theory: When to choose it and how to use it. IEEE Transactions on Professional Communication, 57(2), 123-146. https://doi.org/10.1109/TPC.2014.2312452

Mahmoud, A. B., Hack-polay, D., Fuxman, L., Massetti, B., \& Al Samarh, A. Z. (2020). Developing and validating a new multi-dimensional scale for anti-social behavior in a higher education setting. Scandinavian Journal of Psychology, 61(4), 502-512. https://doi.org/10.1111/sjop.12635

Majboub, W. (2014). Co-creation of value or co-creation of experience? Interrogations in the field of cultural tourism. International Journal of Safety and Security in Tourism, 7(7), 12-31.

Malca, O., Bolaños, J. P., Acedo, F. J., Rubio Donet, J. L., \& Peña-Vinces, J. (2020). Relational flexibility norms and relationship-building capabilities as a mediating mechanism in export performance: insights from exporting SMEs in an emerging economy, Peru. International Journal of Emerging Markets (in press). https://doi.org/10.1108/IJOEM-09-2019-0735

Marsh, H. W., \& Hocevar, D. (1985). Application of confirmatory factor analysis to the study of selfconcept: First- and higher order factor models and their invariance across groups. Psychological Bulletin, 97(3), 562-582. https://doi.org/10.1037/0033-2909.97.3.562

Mathis, E. F., Kim, H. (Lina), Uysal, M., Sirgy, J. M., \& Prebensen, N. K. (2016). The effect of co-creation experience on outcome variable. Annals of Tourism Research, 57, 62-75. https://doi.org/10.1016/j.annals.2015.11.023

Maunier, C., \& Camelis, C. (2013). Toward an identification of elements contributing to satisfaction with the tourism experience. Journal of Vacation Marketing, 19(1), 19-39. https://doi.org/10.1177/1356766712468733

Mazur, J., \& Zaborek, P. (2014). Validating Dart Model. International Journal of Management and Economics, 44(1), 106-125. https://doi.org/10.1515/ijme-2015-0012

Mohammadi, F., Yazdani, H. R., Jami Pour, M., \& Soltanee, M. (2021). Co-creation in tourism: a systematic mapping study. Tourism Review, 76(2), 305-343. https://doi.org/10.1108/TR-10-2019-0425

Morosan, C. (2018). An empirical analysis of intentions to cocreate value in hotels using mobile devices. Journal of Hospitality \& Tourism Research, 42(4), 528-562. https://doi.org/10.1177/1096348015597034

Neuhofer, B. (2016). Value co-creation and co-destruction in connected tourist experiences. In A. Inversini, \& R. Schegg (Eds.), Information and communication technologies in tourism 2016 (pp. 779-792). Springer. https://doi.org/10.1007/978-3-319-28231-2_56

Neuhofer, B., Buhalis, D., \& Ladkin, A. (2015). Smart technologies for personalized experiences: a case study in the hospitality domain. Electronic Markets, 25, 243-254. https://doi.org/10.1007/s12525-015-0182-1

Nguyen, D. N., Imamura, F., \& Iuchi, K. (2018). Barriers towards hotel disaster preparedness: Case studies of post 2011 Tsunami, Japan. International Journal of Disaster Risk Reduction, 28, 585-594. https://doi.org/10.1016/j.ijdrr.2018.01.008

Oh, H., Fiore, A. M., \& Jeoung, M. (2007). Measuring experience economy concepts: tourism applications. Journal of Travel Research, 46(2), 119-132. https://doi.org/10.1177/0047287507304039

Oliver, R. L. (1997). Satisfaction: a behavioral perspective on the consumer. Irwin/McGraw-Hill.

Otto, J. E., \& Ritchie, J. R. B. (1996). The service experience in tourism. Tourism Management, 17(3), 165-174. https://doi.org/10.1016/0261-5177(96)00003-9 
Podsakoff, P. M., MacKenzie, S. B., Lee, J. Y., \& Podsakoff, N. P. (2003). Common method biases in behavioral research: a critical review of the literature and recommended remedies. Journal of Applied Psychology, 88(5), 879-903. https://doi.org/10.1037/0021-9010.88.5.879

Polo Peña, A. I., Frías Jamilena, D. M., \& Rodríguez Molina, M. Á. (2014). Value co-creation via information and communications technology. The Service Industries Journal, 34(13), 1043-1059. https://doi.org/10.1080/02642069.2014.939641

Prahalad, C. K., \& Ramaswamy, V. (2004a). Co-creating unique value with customers. Strategy \& Leadership, 32(3), 4-9. https://doi.org/10.1108/10878570410699249

Prahalad, C. K., \& Ramaswamy, V. (2004b). The future of competition: co-creating unique value with customers. Harvard Business Scool Press.

Prahalad, C. K., \& Ramaswamy, V. (2004c). Co-creation experiences: The next practice in value creation. Journal of Interactive Marketing, 18(3), 5-14. https://doi.org/10.1002/dir.20015

Prebensen, N. K., \& Xie, J. (2017). Efficacy of co-creation and mastering on perceived value and satisfaction in tourists' consumption. Tourism Management, 60, 166-176.

https://doi.org/10.1016/j.tourman.2016.12.001

Qian, J., Law, R., Wei, J., Shen, H., \& Sun, Y. (2021). Hotels' self-positioned image versus customers' perceived image: a case study of a boutique luxury hotel in Hong Kong. Tourism Review, 76(1), 198-211. https://doi.org/10.1108/TR-02-2019-0078

Ramaswamy, V. (2008). Co-creating value through customers' experiences: The Nike case. Strategy and Leadership, 36(5), 9-14. https://doi.org/10.1108/10878570810902068

Ramaswamy, V. (2011). It's about human experiences... and beyond, to co-creation. Industrial Marketing Management, 40(2), 195-196. https://doi.org/10.1016/j.indmarman.2010.06.030

Ranjan, K. R., \& Read, S. (2014). Value co-creation: concept and measurement. Journal of the Academy of Marketing Science, 44(3), 290-315. https://doi.org/10.1007/s11747-014-0397-2

Rather, R. A., \& Sharma, J. (2017). Customer engagement for evaluating customer relationships in hotel industry. European Journal of Tourism, Hospitality and Recreation, 8(1), 1-13.

https://doi.org/10.1515/ejthr-2017-0001

Saha, V., Mani, V., \& Goyal, P. (2020). Emerging trends in the literature of value co-creation: a bibliometric analysis. Benchmarking, 27(3), 981-1002. https://doi.org/10.1108/BIJ-07-2019-0342

Serra-Cantallops, A., Ramón Cardona, J., \& Salvi, F. (2020). Antecedents of positive eWOM in hotels. Exploring the relative role of satisfaction, quality and positive emotional experiences. International Journal of Contemporary Hospitality Management, 32(11), 3457-3477. https://doi.org/10.1108/IJCHM-02-2020-0113

Shaw, G., Bailey, A., \& Williams, A. (2011). Aspects of service-dominant logic and its implications for tourism management: Examples from the hotel industry. Tourism Management, 32(2), 207-214. https://doi.org/10.1016/j.tourman.2010.05.020

Solakis, K., Peña-Vinces, J. C., \& Lopéz-Bonilla, J. M. (2017). DART model from a customer’s perspective: An exploratory study in the hospitality industry of Greece. Problems and Perspectives in Management, 15(2), 536-548. https://doi.org/10.21511/ppm.15(si).2017.07

Spena, R. T., Carida, M., Colurcio, M., \& Melia, M. (2012). Store experience and co-creation: the case of temporary shop. International Journal of Retail \& Distribution Management, 40(1), 21-40. https://doi.org/10.1108/09590551211193586

Taghizadeh, S. K., Jayaraman, K., Ismail, I., \& Rahman, S. A. (2016). Scale development and validation for DART model of value co-creation process on innovation strategy. Journal of Business \& Industrial Marketing, 31(1), 24-35. https://doi.org/10.1108/JBIM-02-2014-0033

Tanev, S., Bailetti, T., Allen, S., Milyakov, H., Durchev, P., \& Ruskov, P. (2011). How do value co-creation activities relate to the perception of firms' innovativeness? Journal of Innovation Economics, 7(1), 131. https://doi.org/10.3917/jie.007.0131 
Vafeas, M., Hughes, T., \& Hilton, T. (2016). Antecedents to value diminution: A dyadic perspective. Marketing Theory, 16(4), 469-491. https://doi.org/10.1177/1470593116652005

Wang, K.-C., Hsieh, A.-T., \& Huan, T.-C. (2000). Critical service features in group package tour: An exploratory research. Tourism Management, 21(2), 177-189. https://doi.org/10.1016/S0261-5177(99)00047-3

Xiang, Z., Schwartz, Z., Gerdes, J. H., \& Uysal, M. (2015). What can big data and text analytics tell us about hotel guest experience and satisfaction? International Journal of Hospitality Management, 44, 120-130. https://doi.org/10.1016/j.ijhm.2014.10.013

Yi, Y., \& Gong, T. (2013). Customer value co-creation behavior: Scale development and validation. Journal of Business Research, 66(9), 1279-1284. https://doi.org/10.1016/j.jbusres.2012.02.026

Zaborek, P., \& Mazur, J. (2019). Enabling value co-creation with consumers as a driver of business performance: A dual perspective of Polish manufacturing and service SMEs. Journal of Business Research, 104, 541-551. https://doi.org/10.1016/j.jbusres.2018.12.067

Zhang, T. (2019). Co-creating tourism experiences through a traveler's journey: a perspective article. Tourism Review, 75(1), 56-60. https://doi.org/10.1108/TR-06-2019-0251

Zhang, T. C., Jahromi, M. F., \& Kizildag, M. (2018). Value co-creation in a sharing economy: The end of price wars? International Journal of Hospitality Management, 71, 51-58. https://doi.org/10.1016/j.ijhm.2017.11.010

Zouni, G., \& Kouremenos, A. (2008). Do tourism providers know their visitors? An investigation of tourism experience at a destination. Tourism and Hospitality Research, 8(4), 282-297.

https://doi.org/10.1057/thr.2008.30 